\title{
EFEKTIVITAS MODEL PEMBELAJARAN PBL (PROBLEM BASED LEARNING) PADA MATERI TATA NAMA SENYAWA TERHADAP HASIL BELAJAR SISWA KELAS X MAN KOTA BANJARBARU
}

\author{
Effectiveness Of PBL (Problem Based Learning) Learning Model In \\ Compound Name Matters On Learning Outcomes Of Class X MAN Students \\ In Banjarbaru City
}

\author{
Lusiyana, Antoni Pardede, Herlina Apriani \\ Program Studi Pendidikan Kimia Fakultas Keguruan dan Ilmu Pendidikan \\ Universitas Islam Kalimantan (Uniska) Muhammad Arsyad Al Banjari, Banjarmasin \\ email: Lucysung98@gmail.com
}

\begin{abstract}
Abstrak. Tujuan dari penelitian ini yaitu untuk mengetahui keefektfan model pembelajaran PBL (Problem Based Learning) pada materi tata nama senyawa terhadap hasil belajar siswa kelas X MIA MAN Kota Banjarbaru tahun pelajaran 2018/2019. Penelitian ini merupakan eksperimen semu dengan desain penelitian One Group Pretest Posttest Design. Sampel dalam penelitian ini berjumlah 16 orang siswa kelas $\mathrm{X}$ MIA MAN Kota Banjarbaru. Pengumpulan data menggunakan soal tes pretest dan posttest yang masing-masing berjumlah 20 butir. Data dari hasil tes yang diperoleh dianalisis menggunakan uji Wilcoxon dengan taraf signifikansi $\alpha=0.05$. Pengujian dengan uji Wilcoxon diperoleh nilai signifikansi sebesar $0,001<0,05$. Sehingga, dapat disimpulkan bahwa diterapkannya model pembelajaran PBL (Problem Based Learning) pada materi tata nama senyawa sangat efektif terhadap hasil belajar siswa kelas X MAN Kota Banjarbaru.

Kata kunci: model PBL, tata nama senyawa, hasil belajar

Abstract. The purpose of this study was to determine the effectiveness of the PBL (Problem Based Learning) learning model on compound nomenclature material on the learning outcomes of class X MIA MAN Banjarbaru City in the academic year 2018/2019. This research is a quasy experiment with One Group Pretest Posttest Design research design. The sample in this study was class X MIA MAN Banjarbaru City, amounting to 16 people. Data collection uses pretest and posttest test questions, each of which consists of 20 items. Data from the test results obtained were analyzed using the Wilcoxon test with a significance level of $\alpha=$ 0.05. Tests using the Wilcoxon test obtained a significance value of $0.001<0.05$. Thus, it was concluded that the implementation of the PBL (Problem Based Learning) model on compound nomenclature material was very effective on the learning outcomes of Grade X MAN Banjarbaru City.
\end{abstract}

Keywords: PBL model, compound nomenclature, learning outcomes

\section{PENDAHULUAN}

Undang-undang No. 20 Tahun 2003 tentang sistem pendidikan nasional diartikan sebagai usaha yang terencana dalam mewujudkan proses pembelajaran, siswa secara aktif dapat mengembangkan potensi yang ada dalam dirinya. Sehingga, potensi spiritual, 
pengendalian diri, kepribadian, kecerdasan, akhlak mulia, keagamaan dan keterampilan dapat dikembangkan oleh siswa (Sugiyono, 2012). Diperlukan kurikulum untuk dapat mewujudkan pendidikan

Kurikulum 2013 merupakan paradigma konstruktivisme, dimana guru sebagai fasilitator, pembimbing dan mediator. Sedangkan siswa diharapkan untuk menemukan informasi secara mandiri dari hasil interaksi mereka dengan lingkungan. Lingkungan itu meliputi metode belajar, media, sistem penilaian, sarana dan prasarana yang dapat membantu dalam proses pembelajaran (Daryanto, 2001). Pembelajaran adalah suatu proses yang melibatkan guru dan siswa didalamnya, dimana untuk mencapai tujuan pendidikan guru dan siswa menggunakan segala sumber daya sesuai dengan yang telah direncanakan dan dipersiapkan (Daryanto, 2009).

Di alam ini, banyak sekali materi yang dapat dipelajari. salah satunya adalah ilmu kimia. Ilmu kimia adalah cabang ilmu pengetahuan alam (IPA) yang mempelajari kajian tentang materi \& perubahannya, struktur, komposisi dan sifat serta energi yang menyertai perubahan tersebut (Akbar, 2013). Pelaksanaan pendidikan pun berdasarkan prinsip pembelajaran yang setiap aktivitas dan kegiatannyanya berpusat pada siswa (Daryanto, 2009). Kondisi tersebut terjadi di MAN Kota Banjarbaru. Dimana kegiatan pembelajaran mata pelajaran kimia masih menggunakan penyampaian materi dan penugasan, yang berdampak nilai mata pelajaran kimia pada materi tata nama senyawa siswa masih banyak yang belum mencapai KKM. Padahal pembelajaran kimia seharusnya merupakan pelajaran yang menyenangkan sebab berhubungan dengan kehidupan sehari-hari, tetapi kebanyakan siswa menganggap pelajaran kimia sebagai mata pelajaran yang sulit dan tidak menyenangkan (Ginayah dkk, 2018).

Rendahnya tingkat ketuntasan siswa kelas $X$ tersebut mengindikasikan kurang efektifnya proses belajar mengajar terhadap materi yang diberikan. Adapun faktor yang dapat menyebabkan kurang efektifnya proses belajar mengajar antara lain: minat belajar siswa yang rendah, belum optimalnya penggunaan model dan media pembelajaran, keterkaitan mata pelajaran kimia dengan fakta-fakta yang terjadi dalam kehidupan sehari-hari belum tergambarkan, sehingga menyebabkan suasana belajar kurang aktif dan kurangnya konsep untuk berpikir lebih kritis dalam memecahkan masalah terhadap materi pelajaran kimia menyebabkan rendahnya pemahaman terhadap materi yang diajarkan.

Kegiatan belajar mengajar yang merupakan bagian dari proses pendidikan, yang saat ini banyak diperlukan perbaikan, seperti kegiatan belajar mengajar yang tidak membosankan, memiliki kreatifitas dan keaktifan yang tinggi. Materi mata pelajaran kimia dikemas agar lebih mudah dihafal/dipahami atau menggunakan model, media dan strategi pembelajaran yang terkini serta proses pembelajaran berpusat pada siswa.

Salah satu model pembelajaran yang dapat digunakan untuk memecahkan kurang efektifnya proses belajar mengajar yang diuraikan sebelumnya adalah PBL. Model pembelajaran PBL mampu membangun proses belajar mengajar menjadi lebih aktif, merumuskan dan mengidentifikasi masalah dan pemecahannya. Model pembelajaran PBL ini dilakukan dengan membagi siswa dalam kelompok kecil yang terdiri dari 4-5 orang, yang secara bersama-sama untuk memecahkan masalah yang diberikan oleh guru.

Berdasarkan uraian diatas. Maka, perlu dilakukan penelitian "Efektivitas Model Pembelajaran PBL (Problem Based Learning) Pada Materi Tata Nama Senyawa Terhadap Hasil Belajar Siswa Kelas X MAN Kota Banjarbaru”. Rumusan masalah 
dalam penelitian ini yaitu apakah model pembelajaran PBL (Problem Based Learning) pada materi tata nama senyawa efektif terhadap hasil belajar siswa kelas X MAN Kota Banjarbaru. Penelitian ini bertujuan untuk mengetahui keefektivan model pembelajaran PBL (Problem Based Learning) pada materi tata nama senyawa terhadap hasil belajar siswa kelas X MAN Kota Banjarbaru.

\section{METODE PENELITIAN}

Penelitian ini adalah eksperimen semu (quasi experimental research) dengan desain penelitian One Group Pretest-Posttest design, yaitu penelitian yang sebelum diberi perlakuan terlebih dahulu dilakukan pretest. Sehingga hasil perlakuan akan lebih akurat, karena membandingkaan kondisi sebelum diberi perlakuan dengan sesudah diberi perlakuan, seperti tabel berikut :

Tabel 1. Desain Penelitian One Group Pretest-Posttest Design

\begin{tabular}{|c|c|c|}
\hline Pretest & Perlakuan & Posttest \\
\hline $\mathrm{O}_{1}$ & $X$ & $\mathrm{O}_{2}$ \\
\hline
\end{tabular}
merupakan nilai tes sesudah diberikan perlakuan (treatment). Sedangkan $\mathrm{X}$ adalah perlakuannya yaitu model pembelajaran PBL (problem based learning), sehingga didapatkan nilai hasil belajar siswa.

Variabel yang akan diteliti dalam penelitian ini terdiri dari variabel bebas yaitu model pembelajaran PBL dan hasil belajar sebagai variabel terikatnya. Variabel merupakan objek dalam penelitian atau apa yang menjadi pusat perhatian suatu penelitian (Arikunto, 2011). Populasi adalah keseluruhan dari subjek penelitian (Arikunto, 2011).

Populasi dalam penelitian ini adalah seluruh siswa kelas X MIA MAN Kota Banjarbaru Tahun Ajaran 2018/2019 yang berjumlah 16 orang. Sampel merupakan bagian dari populasi (Sugiyono, 2012). Teknik pengambilan sampel menggunakan teknik sampling jenuh, dimana semua anggota populasi digunakan sebagai sampel penelitian.

Teknik pengumpulan data menggunakan instrumen penelitian, yaitu tes hasil belajar berupa soal tes multiple choice sebanyak 20 butir untuk masing-masing soal pretest dan posttest. Tes adalah sebuah metode yang digunakan untuk mengukur hasil belajar siswa setelah proses pembelajaran (Masidjo, 1995).

\section{Uji Validitas Instrumen}

Pengujian validitas isi dinilai oleh 3 orang pakar dengan menggunakan daftar cheklist. Menurut Hendrayadi (2017), kriteria kualitas validitas isi dikatakan sangat rendah jika angka percent $<20$, rendah jika angka percent $21-40$, sedang jika angka percent 41-60, tinggi jika angka percent 61-80 dan sangat tinggi jika angka percent 81-100.

Pada uji validitas butir soal diujicobakan kepada siswa kelas XI MIA MAN Kota Banjarbaru dengan jumlah responden sebanyak 27 orang. Perhitungan uji validitas butir soal menggunakan program SPSS 16.0 for windows, adapun kriteria untuk mengetahui apakah item yang digunakan valid atau tidak yaitu jika nilai sig $<0,05$ maka item butir soal tersebut dinyatakan valid. 


\section{Uji Reliabilitas}

Perhitungan uji reliabilitas dalam penelitian ini menggunakan program SPSS 16.0 for windows. instrumen dinyatakan reliabel jika nilai kriteria yang digunakan 0,6 1,00. Untuk menentukan kriteria instrumen yang digunakan bisa dilihat pada tabel 2.

Tabel 2. Kriteria Reliabilitas

\begin{tabular}{cl}
\hline Alpha Cronbach $\left(R^{*}\right)$ & Kriteria \\
\hline $0,80<R^{*} \leq 1,00$ & Sangat tinggi \\
$0,60<R^{*} \leq 0,80$ & Tinggi \\
$0,40<R^{*} \leq 0,60$ & Cukup \\
$0,20<R^{*} \leq 0,40$ & Rendah \\
$0,00<R^{*} \leq 0,20$ & Sangat rendah \\
\hline (Arikunto, 2011$)$ &
\end{tabular}

\section{Uji Tingkat Kesukaran}

Soal yang telah dinyatakan valid dan reliabel, selanjutnya dilakukan perhitungan untuk tingkat kesukarannya. Karena, soal yang baik adalah soal yang tidak terlalu mudah namun tidak pula terlalu sukar. Perhitungan uji tingkat kesukaran soal menggunakan aplikasi anates. Kriteria yang digunakan untuk menentukan tingkat kesukaran suatu soal dapat dilihat pada tabel 3.

Tabel 3. Kriteria Tingkat Kesukaran

\begin{tabular}{cc}
\hline Besarnya P & Kriteria \\
\hline$<0,30$ & Sukar \\
$0,31-0,70$ & Cukup (Sedang) \\
$>0,70$ & Mudah \\
\hline
\end{tabular}

(Sugiyono, 2014)

\section{Uji Daya Pembeda}

Daya pembeda adalah kemampuan suatu soal dalam membedakan siswa yang kemampuan daya pikirnya tinggi dengan siswa yang kemampuan daya pikirnya rendah (Daryanto, 2001). Uji daya pembeda dalam penelitian ini menggunakan aplikasi anates. Untuk mengetahui nilai daya pembeda suatu soal bisa dilihat pada tabel 4 .

Tabel 4. Kriteria Nilai Daya Pembeda

\begin{tabular}{cc}
\hline Nilai & Kriteria \\
\hline$<0,20$ & Buruk \\
$0,21-0,40$ & Sedang \\
$0,41-0,70$ & Baik \\
$0,70-1,00$ & Sangat Baik \\
Bertanda negative & Buruk Sekali \\
\hline
\end{tabular}

(Sugiyono, 2014).

Data yang diperoleh dari pengujian instrumen perlu dianalisis, untuk mengetahui apakah model PBL pada materi tata nama senyawa efektif terhadap hasil belajar siswa kelas X MAN Kota Banjarbaru. Teknik analisis data yang digunakan yaitu 
dengan uji-t. Kriteria yang digunakan dalam pengambilan kesimpulan adalah terima $\mathrm{H}_{\mathrm{a}}$ jika nilai sig $<0,05$ dan terima $\mathrm{H}_{0}$ jika nilai sig $>0,05$.

\section{HASIL PENELITIAN DAN PEMBAHASAN}

Hasil penelitian yang didapat berupa data hasil belajar siswa terhadap mata pelajaran kimia pada materi tata nama senyawa dan pengukurannya menggunakan tes multiple chioce. Dari hasil penelitian didapat data gambar 1.

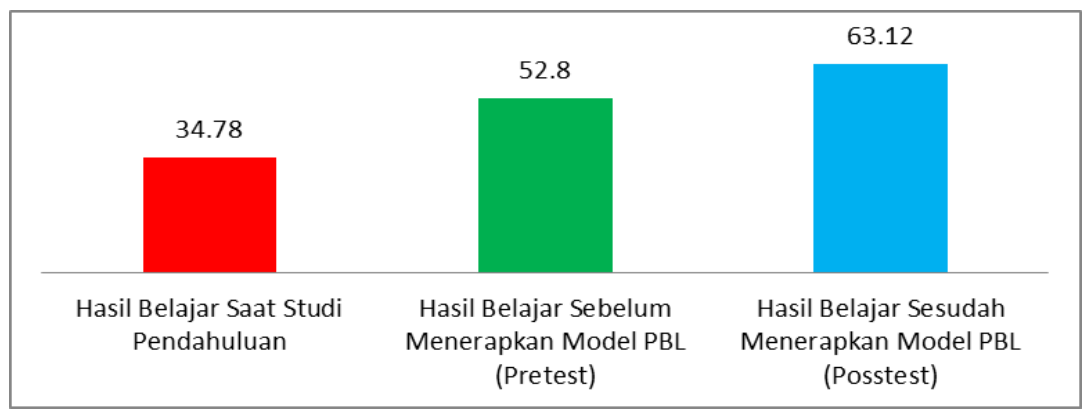

Gambar 1. Perbandingan rata-rata nilai hasil belajar siwa saat studi pendahluan, sebelum dan sesudah menerapkan model pembelajaran PBL

Pada Gambar 1, dapat dilihat bahwa terjadi peningkatan nilai rata-rata hasil belajar siswa saat studi pendahuluan ke pretest sebesar $18,02 \%$ dan posttest meningkat sebesar $28,34 \%$. Untuk rata-rata nilai pretest ke posttest meningkat sebesar $10,32 \%$. Sehingga model pembelajaran PBL berpengaruh terhadap hasil belajar siswa.

Berdasarkan hasil yang ditunjukkan oleh Gambar 1, terdapat peningkatan hasil belajar siswa dari pretest ke posttest yang menunjukkan hasil belajar siswa sesudah menerapkan model PBL lebih tinggi dibandingkan dengan sebelum menerapkan model PBL. Hal tersebut relevan dengan hasil penelitian Zulkardi (2018) yang menunjukkan bahwa pembelajaran menggunakan model kooperatif tipe PBL memberikan pengaruh yang tinggi terhadap hasil belajar siswa.

Peningkatan hasil belajar siswa sesudah menerapkan model pembelajaran PBL sebesar 10,32\%. Meskipun nilai tersebut tidak terlalu besar, akan tetapi dengan menerapkan model pembelajaran PBL terbukti dapat meningkatkan hasil belajar siswa. Dibuktikan dengan rata-rata nilai pretest dan posttest dimana nilai rata-rata belajar pretest siswa sebesar 52,80, sedangkan nilai rata-rata belajar posttest siswa sebesar 63,12 . Hal ini jelas terlihat bahwa hasil rata-rata nilai posttest lebih unggul dibandingkan rata-rata nilai pretest siswa.

Hal tersebut relevan dengan hasil penelitian Arfiyani (2014) yang menunjukkan bahwa dengan menerapkan model pembelajaran problem solving dilangkapi macromedia flash dapat meningkatkan prestasi belajar siswa dari $43,75 \%$ meningkat menjadi $71,88 \%$. Jahro (2015) juga melaporkan hasil penelitiannya, bahwa dengan menerapkan model PBL dapat meningkatkan hasil belajar siswa dari 32,08\% menjadi $85,86 \%$.

Unggulnya rata-rata nilai posttest dibandingkan rata-rata nilai pretest disebabkan oleh model pembelajaran PBL karena siswa menjadi lebih aktif dalam proses 
pembelajaran. Sesuai dengan hasil penelitian Janah (2018) yang menyatakan bahwa penerapan model pembelajaran PBL berpengaruh terhadap hasil belajar siswa kelas XI SMA Negeri 1 Jepara pada materi hidrolisis garam sebesar 35,00\%.

Wasonowati (2014) juga melaporkan hasil penelitiannya, bahwa dengan menerapkan model Problem Based Learning (PBL) pada materi hukum-hukum dasar kimia dikategorikan baik. Dengan persentase nilai hasil belajar siswa kelas X IPA SMA Negeri 2 Surakarta yang mencapai kompetensi inti K13 berturut-turut 78\%, 81,24\% dan $78,13 \%$.

Analisis yang digunakan meliputi uji normalitas dan homogenitas sebagai syarat untuk uji t. Data pretest hasil perhitungan didapat nilai signifikansi sebesar 0,007 sedangan data posttest sebesar 0,015. Data yang diperoleh menggunakan program SPSS 16.0 for windows tersebut berdistribusi tidak normal, karena baik nilai signifikansi pretest maupun posttest lebih kecil dibandingkan $\alpha=0,05$. Data dinyatakan normal jika nilai signifikansi > 0,05 (Santoso, 2012).

Dari hasil perhitungan uji homogenitas menggunakan program SPSS 16.0 for windows diperoleh nilai signifikansi sebesar 0,025. Santoso (2012), data dinyatakan homogen jika nilai signifikansi >0,05. Berdasarkan kriteria tersebut, maka data dinyatakan tidak homogen karena nilai signifikansi $<0,05$.

Berdasarkan kedua pengujian prasyarat analisis data sebelumnya, dapat dikatakan bahwa syarat untuk menggunakan pengujian parametrik uji t tidak terpenuhi. Syarat untuk menggunakan penggujian parametrik uji $t$ adalah jika data tersebut normal dan homogen, sedangkan data nilai yang telah diuji sebelumnya tidak berdistribusi normal dan homogen. Sehingga pengujian hipotesis dalam penelitian ini mengunakan pengujian nonparametrik yaitu uji Wilcoxon.

Menurut Siregar (2013), jika nilai sig lebih besar dari 0,05 maka tidak terdapat pengaruh, jika nilai sig lebih kecil dari 0,05 maka terdapat pengaruh. Hasil perhitungan menggunakan program SPSS 16.0 for windows didapat nilai signifikansi sebesar 0,001 < 0,05 , karena nilai sig lebih kecil dari 0,05 maka dapat disimpulkan model pembelajaran PBL (Problem Based Learning) pada materi tata nama senyawa efektif terhadap hasil belajar siswa kelas X MAN Kota Banjarbaru.

Penerapan model PBL dalam proses pembelajaran mampu meningkatkan hasil belajar siswa. Hal ini disebabkan oleh dengan diterapkannya model PBL setiap siswa terdorong untuk berpikir dan bertanya, bekerjasama, menemukan solusi dalam memecahkan masalah dan membangun kecakapan dalam belajar, sehingga terjadi interaksi antara guru dan siswa serta menjadikan siswa sebagai pusat utama dalam proses pembelajaran. Hal tersebut dilaporkan oleh Daryanto (2009) bahwa pelaksanaan pendidikan harus berdasarkan prinsip pembelajaran berpusat pada siswa.

\section{KESIMPULAN}

Penerapan model pembelajaran PBL memberikan konstribusi sebesar 28,34\% terhadap hasil belajar siswa dari studi pendahuluan, sebesar 10,32\% sejak dilakukannya tes pretest. Berdasarkan hasil penelitian dapat disimpulkan bahwa model pembelajaran PBL (Problem Based Learning) pada materi tata nama senyawa efektif terhadap hasil belajar siswa kelas X MAN Kota Banjarbaru. Hal ini terlihat dari perbedaan rata-rata nilai hasil belajar pretest dan posttest siswa, dibuktikan dengan perhitungan uji Wilcoxon dimana nilai sig $(0,001)$ lebih kecil dari nilai $\alpha$ yakni 0,05 . 


\section{DAFTAR RUJUKAN}

Akbar, F., Anita, Z. dan Harahap, H. (2013). Pengaruh Waktu Simpan Film Plastik Biodegradasi dari Pati Kulit Singkong Terhadap Sifat Mekanikalnya. Jurnal Teknik Kimia Departemen Teknik Kimia Fakultas Teknik Universitas Sumatera Utara, 2(2), 11-15.

Arfiyani, A.Y., Haryono dan Mulyani, B. (2014). Penerapan Model Pembelajaran Problem Solving dilengkapi Macromedia Flash Untuk Meningkatkan Kreativitas dan Prestasi Belajar Pada Materi Hidrokarbon Siswa Kelas X-5 SMA Negeri 3 Boyolali. Jurnal Pendidikan Kimia Universitas Sebelas Maret, 3(1) , 111-116.

Arikunto. (2011). Dasar-Dasar Evaluasi Pendidikan. Jakarta : PT Bumi Aksara.

Cohen, R. J. (2010). Psychological testing and assesment. New York : McGraw-Hill.

Daryanto. (2001). Evaluasi Pendidikan. Jakarta: Rineka Cipta.

Daryanto. (2009). Panduan Pembelajaran Kreatif dan Inovatif. Jakarta: AV Publisher.

Ginayah, L. U., Mashuri. M. T., Wardhani, R. R. A. A. K. (2018). Pengaruh Media Teka-Teki Silang (Tts) Kimia 3d Terhadap Kemampuan Kreatif Siswa Pada Materi Hidrokarbon Kelas X SMA Negeri 12 Banjarmasin. Dalton : Jurnal Pendidikan Kimia dan Ilmu Kimia, 1(2), 14-19.

Hendrayadi. (2017). Validitas Isi: Tahap Awal Pengembangan Kuesioner. Jurnal Riset Manajemen dan Bisnis Fakultas Ekonomi Universitas Islam Attahiriyah, 2(2), 169-178.

Jahro, I.S dan Ridho, D. (2015). Penerapan Model Problem Based Learning Menggunakan Media Exe Learning Untuk Meningkatkan Hasil Belajar dan Kerjasama Siswa Pada Materi Hidrokarbon. Jurnal Pendidikan Kimia Universitas Negeri Medan, 7(3), 80-86.

Janah, C.M., Widodo, T.A. dan Kasmui. (2018). Pengaruh Model Problem Based Learning Terhadap Hasil Belajar dan Keterampilan Sains. Jurnal Kimia Universitas Negeri Semarang, 12(1), 2097-2107.

Masidjo. (1995). Penelitian Pencapaian Hasil Belajar Siswa Di Sekolah. Yogyakarta: Kanisius

Santoso, S. (2012). Panduan Lengkap SPSS Versi 20. Jakarta : PT Elex Media Komputindo

Siregar, S. (2013). Metode Penelitian Kuantitatif. Jakarta: PT Fajar Interpratama Mandiri

Sugiyono. (2014). Metode Penelitian Kuantitatif Kualitatif dan R\&D. Bandung: Alfabeta.

Sugiyono. (2012). Metode Penelitian Pendidikan. Bandung: Alfabeta.

Wasonowati, T. R. R., Redjeki, T. dan Ariani, D. R. S.( 2014). Penerapan Model Problem Based Learning (PBL) Pada Pembelajaran Hukum-Hukum Dasar Kimia Ditinjau dari Aktivitas dan Hasil Belajar Siswa Kelas X IPA SMA Negeri 2 Surakarta. Jurnal Pendidikan Kimia Universitas Sebelas Maret, 3(3), 66-75.

Zulkardi, W., Kurniati, T. dan Fitriani. (2018). Pengaruh Model Pembelajaran Problem Based Learning Pada Sub Materi Tata Nama Senyawa Hidrokarbon Terhadap Hasil Belajar Siswa Kelas Xi Mia Sma Negeri 1 Pemangkat. Jurnal Pendidikan Kimia Universitas Muhammadiyah Pontianak, 6(2), 1-7. 